\title{
The effects of Annonaceae and Amaryllidaceae extracts in controlling the Thrips tabaci Lindeman (Thysanoptera: Thripidae)
}

\author{
Ana Isabel Giraldo Rivera ${ }^{1} \oplus$, Gloria Edith Guerrero Alvarez ${ }^{1} \oplus$, Juan Pablo Arrubla ${ }^{1} \oplus$, Luz Marina Baena ${ }^{1} \oplus$, \\ Diego Paredes Cuervo'®${ }^{1}$, Melissa Andrea Gomez Benitez ${ }^{1}[0$

\footnotetext{
1 Universidad Tecnológica de Pereira, Pereira, Risaralda, Colombia. E-mail: aigiraldo@utp.edu.co; gguerrero@utp.edu.co; juanpablo77@utp.edu.co; Imbaena@utp.edu.co; diparede@utp.edu.co; meangomez@utp.edu.co
}

ABSTRACT: The objective of the present study was to evaluate the effects of Annona muricata and Allium fistulosum extracts in controlling Thrips tabaci and to identify the main secondary metabolites. We obtained extracts from A. muricata seeds and of A. fistulosum $L$. leaves. An in vitro model for evaluating insecticide against $T$. tabaci was performed. The effect of the extracts was individually and subsequently assessed in mixtures for determining the mean lethal concentration. According to the results obtained with $T$. tabaci, the $A$. muricata L. extract showed $\mathrm{LC}_{50}=82.93 \mathrm{mg} \mathrm{L}^{-1}$, the essential oil showed $\mathrm{LC}_{50}=335.29 \mathrm{mg} \mathrm{L}^{-1}$, and the hydrolate showed $\mathrm{LC}_{50}=2348.84 \mathrm{mg} \mathrm{L}^{-1}$. The combinations of extracts reached mortality rates between $50 \%$ and $72.62 \%$, which are promising results as alternatives for the comprehensive management of this pest. The analysis of the Annonaceae extract using HPLC indicated the presence of acetogenins and alkaloids, and the analysis of $A$. fistulosum $\mathrm{L}$. extracts using GC-MS showed the presence of volatile sulfur compounds. The phenol and total flavonoid contents were also determined in the essential oil and in the A. fistulosum L. hydrolate.

Key words: acetogenins; essential oil; hydrolate; polar extract

\section{Efecto de extractos de Annonaceae y Amaryllidaceae para el control del piojito negro de la cebolla, Thrips tabaci Lindeman (Thysanoptera:Thripidae)}

RESUMEN: El objetivo de este estudio fue evaluar el efecto de los extractos de Annona muricata, y de Allium fistulosum L. para el control del Thrips tabaci L., e identificar los principales metabolitos secundarios a los que se les atribuye la actividad. Se obtuvo un extracto polar a partir de la semilla de Annona muricata y dos extractos de las hojas de Allium fistulosum L. Se implementó un modelo in vitro para la evaluación insecticida frente a Thrips tabaci L. Se evaluó el efecto de los extractos de manera individual y posteriormente en mezclas determinando la concentración letal media. Según los resultados el extracto de $A$. muricata L. presentó un $\mathrm{CL}_{50}=82.93 \mathrm{mg} \mathrm{L}^{-1}$, el aceite esencial de $\mathrm{CL}_{50}=335.29 \mathrm{mg} \mathrm{L}^{-1}$ y el hidrolato de $\mathrm{CL}_{50}=2348.84$ $\mathrm{mg} \mathrm{L}^{-1}$. Las combinaciones de los extractos alcanzaron tasas de mortalidad entre el $50 \%$ y $72.62 \%$, resultados promisorios como alternativa para el manejo integral de esta plaga. El análisis por Cromatografía liquidad de Alta Eficiencia (HPLC) del extracto de Annonaceae indicó la presencia de Acetogeninas y Alcaloides, y el análisis por Cromatografía de gases acoplado a espectrometría de masas (GC-MS) de los extractos de Allium fistulosum L. evidenció la presencia de compuestos volátiles sulfurados. Adicionalmente, se determinó en el Aceite esencial y en el Hidrolato de Allium fistulosum L. el contenido de fenoles y flavonoides totales.

Palabras claves: acetogeninas; aceite esencial; hidrolato; extracto polar 


\section{Introduction}

The long green onion (Allium fistulosum L.), which belongs to the Amaryllidaceae family, is listed among the Allium species as one of the most economically viable ones due to its wide use as a condiment and its medicinal properties, and it is considered as one of the most appetizing products of the world cuisine. Due to its high production volume, onion ranks second among vegetables, and currently more than 3.7 million hectares have been planted in approximately 175 countries (Ortiz et al., 2012; Chang et al., 2016).

The technological factors involved in onion production (such as weight loss in the onion, their color, the presence of fungi, deterioration of the bulbs, and the presence of stems and sprouts) are mainly associated with complex health problems and the deterioration of environmental resources, which result in low yields, require intensive use of agrochemicals, and have significantly increased production costs. This has expedited environmental deterioration and accentuated risks to human health (Arevalo et al., 2014).

The phytosanitary problems include a wide range of fungi, insects, and mites that attack onions, of which "thrips" (Thrips tabaci $\mathrm{L}$.) is the main insect species. These small sucking insects are considered the plague that mostly affects onion crops. The infestation is characterized by silver spots or streaks on the leaves. Experimental data show that an average of 150 thrips cause losses of approximately $40 \%$ in total crop production. A wide range of control measures are available to reduce thrips damage in Allium crops (Zamar et al., 2007), where the use of chemical inputs has become indispensable due to the phytopathological problems that cause crop diseases.

However, chemical control is no longer deemed sufficient as high resistance has been reported (Martin et al., 2003; Lebedev et al., 2013; Nazemi et al., 2016). The use of entomopathogenic nematodes and fungi has been implemented as an alternative for thrips control (Patil et al., 2016; Azazy et al, 2018) along with the use of biopesticides from plant extracts, with promising results (Khaliq et al., 2014; Satyanarayana \& Singh, 2016).

The use of biopesticides from plant extracts as a strategy for controlling insects is safe for the environment and human health (Leite et al., 2012; Celestino et al., 2016). Several studies have been reported where pepper (Capsicum frutescens L.) stands out in the Solanaceae family, the castor oil plant (Ricinus comunis I.) stands out in the Euphorbiaceae family, and plant extracts such as neem (Azadirachta indica A. Juss) and paradise (Melia azedarach L.) stand out in the Meliaceae family (Celis et al., 2008).

Among other families with promising plant extracts that are used as biopesticides are Amaryllidaceae, where garlic (Allium sativum L.) and long green onion (A. fistulosum L.) with various biological activities stand out, and their cytoxicities are of interest as options for the prevention and control of insect-pest infestation (Roldán et al., 2007; Denloye, 2010; Llana-Ruiz-Cabello et al., 2015) and Annonaceae, where the insecticide activity of different fruit species is highlighted, $A$. muricata L. being the most studied (Moghadamtousi et al., 2015; Dos Santos et al., 2018).

The long green onion ( $A$. fistulosum L.) is of great importance in Colombia due to the great demand for this product at a national level as it has significantly contributed to the development and generation of employment in rural areas. However, the use of pesticides for pest control has generated a problem for the safety and environmental impact of onion crops in the municipality of Pereira, Colombia (Guzmán \& Palacios, 2008) because chemical insecticides applied by runoff or infiltration processes reach water sources and remain in the environment through bioaccumulation and/or biomagnification, causing pollution processes (RAPAL Uruguay, 2010).

To address this problem, considering that Colombia has a great diversity of fruit species (Murillo, 2001) and various onion crops of economic importance as well as different species of Amaryllidaceae (Guzmán \& Palacios, 2008), the current investigation aimed to establish the potential of $A$. muricata $\mathrm{L}$. and $A$. fistulosum L. extracts for exerting control over the insect-plague by $T$. tabaci L. that affects onion plantations.

\section{Materials and Methods}

\section{Vegetable material}

The seeds of $A$. muricata $\mathrm{L}$. were obtained from fruits of crops grown in the municipality of Pereira, Department of Risaralda, Colombia, in 2017. The long green onion ( $A$. fistulosum L.) was harvested on the "El Manzano" farm, located in the Department of Risaralda, Colombia, in 2017. The material was subsequently transported to the OLEQUIMICA research group's laboratory at the Technological University of Pereira.

\section{Obtaining the Annona muricata L. extract}

The seeds were washed with TEGO 51 soap and dried in an oven at $37{ }^{\circ} \mathrm{C}$. Subsequently, the material was crushed in a blade mill and the powder obtained was subjected to extraction by passive maceration at room temperature with regular agitation for one week using ethanol as the solvent at a 1:4 ( $\left.w^{-1}\right)$ solvent-sample ratio in accordance with that used in previous studies (Castro et al., 2010; Giraldo \& Guerrero, 2018); the macerate was then vacuum filtered and concentrated in a rotary evaporator under reduced pressure and kept at $4{ }^{\circ} \mathrm{C}$.

\section{Obtaining the Allium fistulosum L. extracts}

The onion leaves were washed with plenty of water to remove dirt. The hydrolate and the essential oil were obtained using hydro distillation from leaves and stems of fresh onion (A. fistulosum L.) with a 1:1 sample-solvent ratio. The essential oil obtained was received in an ice bath and then subjected to a liquid-liquid extraction using ethyl acetate as a solvent. The solvent was removed by rota-evaporation and nitrogen flow and was preserved at $4{ }^{\circ} \mathrm{C}$ for further analyses. 
Preliminary lethality test with Artemia salina (BSLT)

A preliminary evaluation of the bioactivity and toxicity of the A. muricata L. and A. fistulosum L. extracts was performed, for which the Artemia salina nauplii methodology was implemented with some modifications (McLaughlin, 2008). Eggs were hatched in a $3.7 \%$ artificial sea solution at $30{ }^{\circ} \mathrm{C}$ for $48 \mathrm{~h}$. Each toxicity bioassay was performed in triplicate, and four concentrations of each extract were analyzed. Ten nauplii were deposited; an ethanol solution was used as a positive control, while the artificial sea solution was used as a negative control. Mortality was recorded $24 \mathrm{~h}$ after exposure and $\mathrm{LC}_{50}$ was determined using the Probit method.

\section{Assessment of biocidal activity against Thrips tabaci L.}

The evaluation of the biocidal activity of the extracts was performed at the El Jardín farm (Risaralda). Second and third instar stage of Thrips tabaci L. larvae were net-collected from onion growing ( $4^{\circ} 46^{\prime} 24.9^{\prime \prime}, \mathrm{E} 75^{\circ} 38^{\prime} 0.04^{\prime \prime}$ ) located near Pereira, Colombia, from early January to late March 2018. The bioassays were performed at room temperature of $23^{\circ} \mathrm{C}$ $\pm 1{ }^{\circ} \mathrm{C}$, with a relative humidity $(\mathrm{RH})$ of $25 \% \pm 10 \%$. Based on previous tests (Martin et al., 2003), plastic Petri boxes having dimensions of $16 \mathrm{~cm}$ (diameter) x $1.5 \mathrm{~cm}$ (height) were employed; holes were made in the lid of the boxes to aerate their content.

Plants infested with the pest were chosen, and transverse cuts were made in the leaves where larvae were present. These pieces were deposited in Petri boxes with an average of 10 larvae per box (experimental unit). Survival of larvae was evaluated 24 hours after the application of the extracts; individuals showing no mobility were considered dead.

The mixture of the extracts was applied using a micro atomizer which helped to completely impregnate the onion leaves. The doses were tested in independent trials and with the same review and control treatment. The experimental design used in each trial was randomized, with six repetitions per treatment. The control experiments were performed in parallel; a blank containing the same amount of dimethyl sulfoxide (DMSO) was used to dissolve the extracts and an insecticide of toxicological category II that is often used by onion growers was used to establish a relative level of activity of the active compounds of the extracts..

Insecticidal effect of the extracts and selectivity of the concentrations in a mixture

The raw extracts were individually evaluated at different concentrations to establish a range of concentrations for the extract combination. The $A$. muricata $\mathrm{L}$. extract was evaluated at $10,50,100$, and $150 \mathrm{mg} \mathrm{L}^{-1}$, while the essential oil was assessed at 100,250 , and $500 \mathrm{mg} \mathrm{L}^{-1}$ and the hydrolate at 1853,9265 , and $18530 \mathrm{mg} \mathrm{L}^{-1}$. LC $\mathrm{L}_{50}$ was determined by the Probit method after $24 \mathrm{~h}$ of exposure.

Three combinations were evaluated at different concentrations based on the response obtained from the individual extracts. The $A$. muricata $L$. extract and the onion's essential oil were prepared at a concentration ranging from
100 to $200 \mathrm{mg} \mathrm{L}^{-1}$, and the hydrolate at a concentration ranging from 1850 to $9265 \mathrm{mg} \mathrm{L}^{-1}$. DMSO was used as a solvent to homogenize the preparation of the extracts and blend, and they were adjusted to $25 \mathrm{~mL}$ with distilled water.

\section{Instrumentation}

For the chromatographic profile of the Annonaceae extract, a Jasco 2000 plus chromatograph liquid (LC 2000Plus Analytical, Japan) was used, which was equipped with quaternary gradient pump (PU-2089 Plus), an intelligent autosampler (AS-2059 Plus), a column oven (CO-2065 Plus), a diode array smart detector (MD-2015 Plus), and chromatograms were recorded using the EZCHrom Elite software. A UV-Visible Shimadzu spectrophotometer (UV-1700 PharmaSpec, Japan) was used for the analysis of the total phenol and flavonoid content. For the determination of sulfur compounds in the onion extracts, a Supelco SPME polydimethylsiloxane fiber (PDMS, $100 \mu \mathrm{m}$ ) was used, which was conditioned according to the manufacturer's instructions. Gas chromatography-mass spectrometry (GC-MS) analyses were performed on a GC Shimadzu QP 2010 plus gas chromatograph, with electronic pressure control, equipped with split/splitless injector, on an SH RXi column ( $30 \mathrm{~m}, 0.25 \mathrm{mmID}, 0.50 \mu \mathrm{m} \mathrm{df}$ ), coupled to a QP 2020 mass spectrometer (GC-MS QP2020 Shimadzu, Japan).

Identification of acetogenins and alkaloids with high efficiency liquid chromatography (HPLC)

A chemical analysis of the $A$. muricata $L$. extract was carried out with high performance liquid chromatography (HPLC) using a $\mu$ Bondapak $\mathrm{C} 18$ reverse phase column $\left(125^{\circ} \mathrm{A} \times 300\right.$ $\mathrm{mm} \times 7.8 \mathrm{~mm}$ id) $10 \mu \mathrm{m}$. An isocratic method using a mobile phase of 75:25 acetonitrile:water was used. The separation was performed at a wavelength ranging from 200 to $400 \mathrm{~nm}$. Running time was $60 \mathrm{~min}$. An injection volume of $20 \mu \mathrm{L}$ and a concentration for each test sample of $100 \mu \mathrm{g} \mathrm{mL}^{-1}$ were used.

Identification of volatile sulfur compounds with gas chromatography-mass spectrometry (GC-MS)

The presence of sulfur compounds presents in the essential oil extracted from onion and in the hydrolate was determined by micro extraction in solid phase using Supelco polydimethylsiloxane (PDMS, $100 \mu \mathrm{m}$ ) fiber. Such fiber was conditioned in the injection port at $250^{\circ} \mathrm{C}$ for $30 \mathrm{~min} ; 5 \mathrm{~mL}$ of sample was taken for the hydrolate and subjected to constant agitation for $30 \mathrm{~min}$ at $50{ }^{\circ} \mathrm{C}$. Next, the PDMS fiber was exposed in the head space for $30 \mathrm{~min}$, as followed in previous studies (Soto et al., 2015). The essential oil was diluted at a ratio of 1:1000 with distilled water prior to testing, and the same procedure used for the hydrolate was followed.

The qualitative analysis was performed by electronic impact ionization at $70 \mathrm{eV}$ through GC-MS using Shimadzu GC2010 Plus + QP2020, with helium as the entrained gas (Flow: $0.94 \mathrm{~mL} \mathrm{~min}^{-1}$ ) and a capillary column of fused silica SH-Rxi-5Sil MS (30 $\mathrm{m} \times 0.25 \mathrm{~mm} \times 0.25 \mu \mathrm{m}$ ). Temperature programming was implemented at $40{ }^{\circ} \mathrm{C}$ as the initial temperature which was maintained for $2 \mathrm{~min}$ and then increased at a rate of $3{ }^{\circ} \mathrm{C}$ 
$\mathrm{min}^{-1}$ until it reached $90{ }^{\circ} \mathrm{C}(3 \mathrm{~min})$; it was then increased to 3 ${ }^{\circ} \mathrm{C} \cdot \mathrm{min}^{-1}$, up to $150{ }^{\circ} \mathrm{C}$ (5 min), and finally a heating rate of 10 ${ }^{\circ} \mathrm{C} \mathrm{min}^{-1}$ was used until it reached $280{ }^{\circ} \mathrm{C}$ ( $1 \mathrm{~min}$ ), for a total running time of $60.67 \mathrm{~min}$. The injection mode was splitless with a sampling time of $1.5 \mathrm{~min}$ in scan mode (range 35-500 $\left.\mathrm{m} \mathrm{z}^{-1}\right)$. Identification of the compounds was performed by comparison using NIST14 mass spectral library.

\section{Total phenol content}

For determination of the total phenol content, the methodology described by Calderón-Oliver et al., (2016) was used with some modifications; $50 \mu \mathrm{L}$ of each extract was taken, and then $250 \mu \mathrm{L}$ of distilled water and $250 \mu \mathrm{L}$ of Folin-Ciocalteau reagent (1:1) were added. The mixture was homogenized and pre-incubated for $5 \mathrm{~min}$. Next, $750 \mu \mathrm{L}$ of a $20 \% \mathrm{Na}_{2} \mathrm{CO}_{3}$ solution was added and incubated for $30 \mathrm{~min}$ at room temperature and protected from light. Absorbance was then measured at a wavelength of $760 \mathrm{~nm}$. The results were expressed as mg eq. gallic acid (EAG). $100 \mathrm{~g}^{-1}$ dry sample. All extracts were analyzed in triplicate.

\section{Total flavonoid content}

The flavonoid content was determined on the basis of the methodology described by Garrido et al. (2013) with some modifications; $20 \mu \mathrm{L}$ of the samples were taken and $600 \mu \mathrm{L}$ of $95 \%$ ethanol, $40 \mu \mathrm{L}$ of a $10 \%$ aluminum chloride solution, $40 \mu \mathrm{L}$ of magnesium acetate solution (1 M), and $1120 \mu \mathrm{L}$ of distilled water were added. The mixture was then homogenized and allowed to incubate for $30 \mathrm{~min}$ at room temperature and protected from light. Finally, absorbance was measured at 470 $\mathrm{nm}$. The assays were performed in triplicate and the results were expressed in equivalent milligrams of quercetin $(\mathrm{mg}$ EQ.100 $\mathrm{mL}^{-1}$ of sample).

\section{Statistical analysis}

The results of the biocidal activity are presented as a percentage of average mortality (Mean \pm SD). The mortality data were subjected to the concentration-response analysis using the Probit tool of the software Infostat version 2008. Based on the mathematical model adjusted for the observed data, the mean lethal concentration (LC50) values were determined. In the comparison of mortality data, for individual extracts and combination between extract were first submitted of test normality and variances using 0.01 as the significance value. Then, the Tukey test was performed for comparision of the means at a statistical significance level of 0.05 threshold with the statistical program Infostat.

\section{Results and Discussion}

According to the results of the Artemia salina test, all the evaluated extracts are active with $\mathrm{LC}_{50}$ values $<1000 \mu \mathrm{g} \mathrm{mL}^{-1}$, which gives them biocidal potential (Grzybowski et al., 2012). In the present study, we emphasized that the $A$. muricata $\mathrm{L}$. extract presented an average lethal concentration of $\mathrm{LC}_{50}=$ $2.558 \mu \mathrm{g} \mathrm{mL}^{-1}\left(<10 \mu \mathrm{g} \mathrm{mL}^{-1}\right)$, which classifies it as highly active; the essential oil with a $\mathrm{LC}_{50}=97.2 \mu \mathrm{g} \mathrm{mL}^{-1}\left(<100 \mu \mathrm{g} \mathrm{mL}^{-1}\right)$ is considered very active and, finally, the hydrolate with a $\mathrm{LC}_{50}=$ $390.7 \mu \mathrm{g} \mathrm{mL}^{-1}$ is considered moderately active.

The preliminary results obtained with Artemia salina nauplii allowed to continue with the in vitro evaluation of the three extracts with T. tabacci. The percentages of mortality reached by each type of extract are presented in Figure 1. As can be observed, the $A$. muricata $L$. extract reached the highest percentage of mortality (77\%) at a concentration of $150 \mathrm{mg} \mathrm{L}^{-1}$, while the essential oil of $A$. fistulosum $\mathrm{L}$. reached
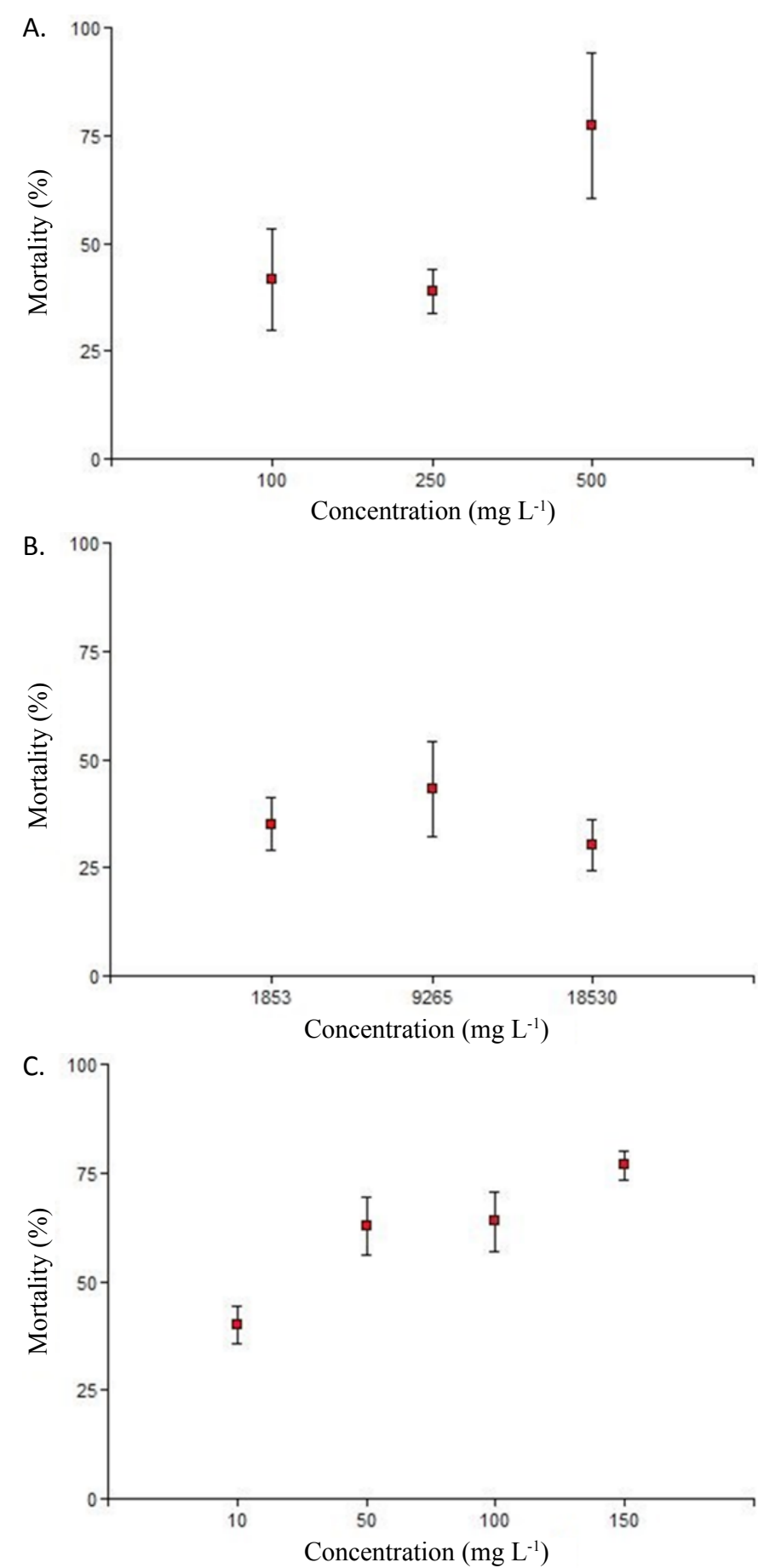

Figure 1. Mortality seen in the biocidal assays against Thrips tabaci L. with A. Allium fistulosum L. essential oil B. A. fistulosum L. hydrolate C. Annona muricata L. polar extract. 
the same percentage of mortality, but at a concentration of $500 \mathrm{mg} \mathrm{L}^{-1}$. On the contrary, the hydrolate did not reach lethality percentages higher than $50 \%$ even at concentrations higher than $1000 \mathrm{mg} \mathrm{L}^{-1}$, and the maximum percentage of lethality reached was $43 \%$ at $9265 \mathrm{mg} \mathrm{L}^{-1}$. No significant differences were noted between the treatments applied for the hydrolate and the essential oil.

The results of the insecticidal activity of $A$. muricata $L$. extract showed very similar percentages of mortality at the concentrations used $\left(50,100\right.$, and $\left.150 \mathrm{mg} \mathrm{L}^{-1}\right)$. No statistically significant differences were found between them, which indicates that there was no increase in the mortality of thrips larvae using extract concentrations higher than $50 \mathrm{mg} \mathrm{L}^{-1}$.

According to the findings of the Probit analysis, the polar extract of $A$. muricata L. showed the lowest mean lethal concentration $\left(\mathrm{LC}_{50}=82.93 \mathrm{mg} \mathrm{L}^{-1}\right)$, while the essential oil of $A$. fistulosum $\mathrm{L}$. presented a concentration that was approximately four times that of the $A$. muricata $L$. extract $\left(\mathrm{LC}_{50}=335.29 \mathrm{mg}\right.$ $\left.\mathrm{L}^{-1}\right)$, and the hydrolate showed a concentration approximately 28 times that of the $A$. muricata $\mathrm{L}$. extract $\left(\mathrm{LC}_{50}=2348.84 \mathrm{mg}\right.$ $\left.\mathrm{L}^{-1}\right)$. This indicates that the extract with the highest lethality was that of $A$. muricata $L$.

According to the HPLC analysis of the of $A$. muricata $\mathrm{L}$. extract (Figure 2), 27 compounds were recognized, of which the ones that eluted the first 15 min correspond, according to their ultraviolet spectrum, to isoquinoline alkaloids (Figure 2 A). These are probably of the aphorfinic type according to their absorbance maxima between 265 and $357 \mathrm{~nm}$ (Egydio-Brandão et al., 2017). Conversely, from 18 to 57 min, acetogenin-like compounds eluted, according to their UV spectrum (Figure $2 b$ ), with absorbance maxima between 200 and $220 \mathrm{~nm}$, which is characteristic of these metabolites
(Giraldo \& Guerrero, 2018).

The results of the analysis by GC-MS of the essential oil and the hydroxide of $A$. fistulosum L. are presented in Table 1. For the essential oil, 19 sulfide compounds were identified, of which the dipropyl disulfide was the major compound with a percentage of relative area of $44.21 \%$. While, for the hydrolate, a total of eight compounds were found, of which dipropyl disulfide and dipropyl trisulfide were the most abundant, with percentages of relative area of $31.84 \%$ and $31.99 \%$, respectively. The compounds identified are characteristic of the Amaryllidaceae family, according to reports by other authors (Kameoka et al., 1984; Lanzotti, 2006; Gîtin et al., 2014).

According to the results of the total phenol and flavonoid content analysis for $A$. fistulosum L. extracts, it could be established that the hydrolate is more concentrated in these compounds than the essential oil. The hydrolate had a total phenolic content of $2552.01 \pm 11.54 \mathrm{mg}$ EAG $100 \mathrm{~g}^{-1}$ and 1153 $\pm 0.119 \mathrm{mg}$ EQ $100 \mathrm{~mL}^{-1}$ of flavonoids, while the essential oil had a concentration of $905.33 \pm 24.95 \mathrm{mg}$ EAG $100 \mathrm{~g}^{-1}$ of total phenols and $7679 \pm 0.297 \mathrm{mg}$ EQ $100 \mathrm{~mL}^{-1}$ of flavonoids. The values obtained in this study are above those reported by other authors for polar extracts from different parts of $A$. fistulosum L. (Chang et al., 2016), which can be attributed to the study material and its origin (Pino et al., 2013).

According to the chemical analysis conducted, the $A$. muricata L. extract is characterized by the presence of two types of secondary metabolites that provide it with an important activity; acetogenins, potent inhibitors of complex I (NADH: ubiquinone oxidoreductase) of the mitochondrial electron transport system and of the NADH coenzyme in the cell membranes of arthropods, causing paralysis in insects, as it

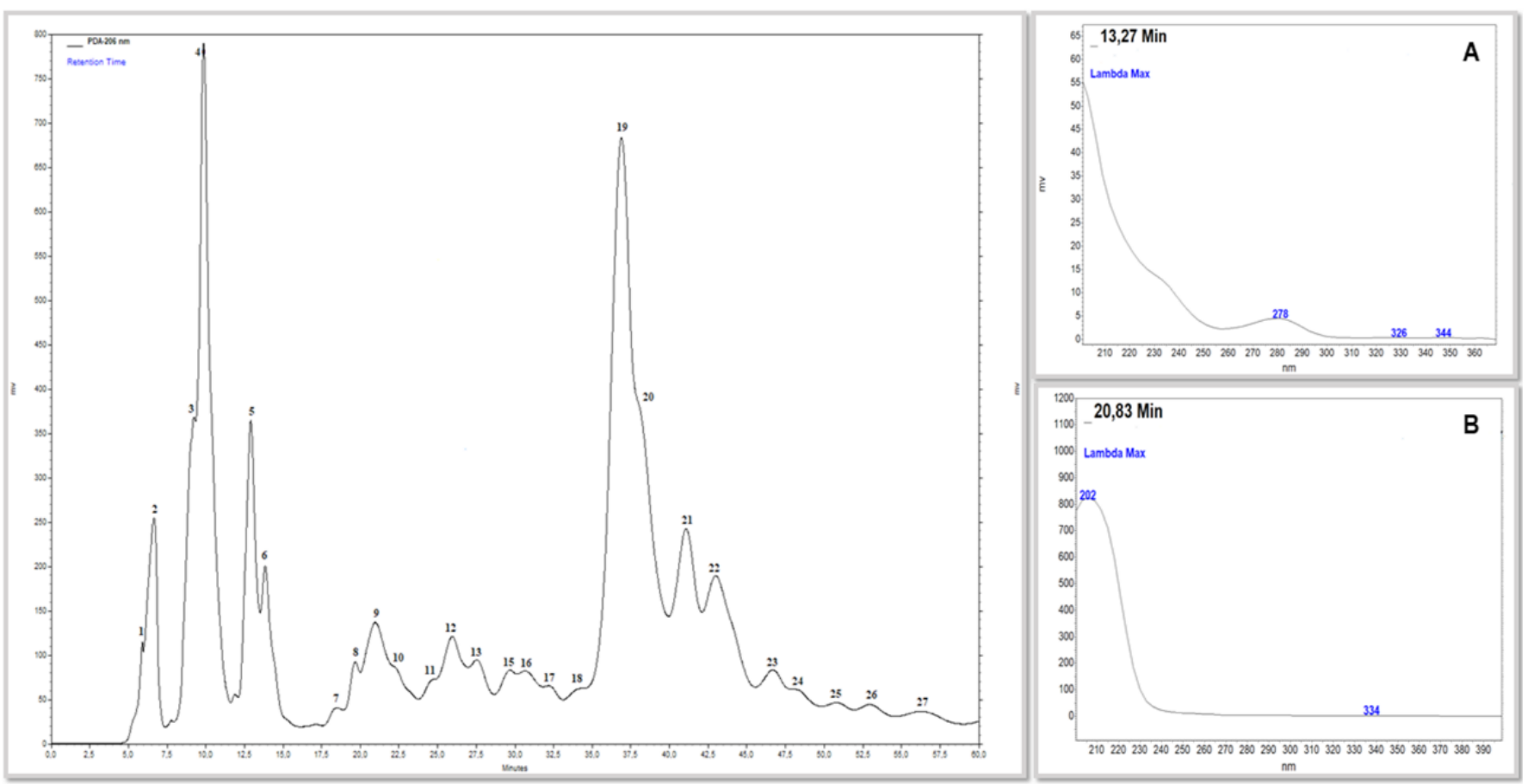

Figure 2. Chromatographic profile of Annonaceae extract A. Characteristic UV spectrum of isoquinolinic alkaloids B. Characteristic UV spectrum of Acetogenins. 
Table 1. Volatile sulfur compounds identified in Allium fistulosum L.

\begin{tabular}{|c|c|c|c|c|}
\hline Peak & Compound & IR & $\% \mathrm{SI}$ & \%Area \\
\hline \multicolumn{5}{|c|}{ Essential oil } \\
\hline 1 & 3,4-dimethyl thiophene & 902 & 87 & 0.71 \\
\hline 2 & methyl propyl disulfide & 929 & 87 & 0.75 \\
\hline 3 & (E)-1-Methyl-2-(prop-1-en-1-yl) disulfane & 936 & 88 & 0.62 \\
\hline 4 & Dipropyl disulfide & 1110 & 95 & 44.21 \\
\hline 5 & 1-Allyl-2-isopropyldisulfane & 1115 & 90 & 8.58 \\
\hline 6 & Methyl propyl trisulfide & 1147 & 89 & 1.48 \\
\hline 7 & (E)-1-Methyl-3-(prop-1-en-1-yl) trisulfane & 1161 & 89 & 0.22 \\
\hline 8 & Isothiocyanato cyclohexane & 1229 & 94 & 1.39 \\
\hline 9 & Dipropyl trisulfide & 1327 & 93 & 8.41 \\
\hline 10 & (E)-1-(Prop-1-en-1-yl)-3-propyltrisulfane & 1333 & 90 & 14.32 \\
\hline 11 & 5-Methyl-1,2,3,4-tetrathiane & 1363 & 85 & 0.12 \\
\hline 12 & Methyl 1-(methylthio)propyl disulfide & 1418 & 90 & $0 ., 69$ \\
\hline 13 & 1,2,4,5-Tetrathiane, 3,6-diethyl-, trans- & 1588 & 87 & 9.60 \\
\hline 14 & Methyl 1-(1-propenylthio) propyl disulfide, & 1591 & 91 & 6.29 \\
\hline 15 & 1,2,3,5-Tetrathiane, 4,6-diethyl-, cis- & 1618 & 90 & 0.84 \\
\hline 16 & 6-Ethyl-4,5,7,8-tetrathianonane & 1632 & 86 & 0.56 \\
\hline 17 & 4,7-Diethyl-1,2,3,5,6-pentathiepane & 1873 & 89 & 1.22 \\
\hline \multicolumn{5}{|c|}{ Hydrolate } \\
\hline 1 & Dipropyl disulfide & 1108 & 95 & 31.84 \\
\hline 2 & (E)-1-(Prop-1-en-1-yl)-2-propyldisulfane & 1111 & 91 & 5.69 \\
\hline 3 & Methyl propyl trisulfide & 1146 & 95 & 16.46 \\
\hline 4 & Dipropyl trisulfide & 1323 & 95 & 31.99 \\
\hline 5 & (Z)-1-(Prop-1-en-1-yl)-3-propyltrisulfane & 1327 & 92 & 4.00 \\
\hline 6 & (E)-1-(Prop-1-en-1-yl)-3-propyltrisulfane & 1336 & 93 & 6.08 \\
\hline 7 & 5-Methyl-1,2,3,4-tetrathiane & 1361 & 93 & 3.12 \\
\hline 8 & Dipropyl tetrasulfide, & 1557 & 87 & 0.82 \\
\hline
\end{tabular}

The percentage (\%) of the compounds' relative area comprises only the sulfides.

affects normal nerve transmission that eventually leads to death (Nwankwo et al., 2015; Souza et al., 2017); and isoquinoline alkaloids, which are characterized by affecting acetylcholine in the sodium channels in the membranes of nerve cells, which also leads to the insect's death (Rattan, 2010).

The essential oil and the hydrolate, according to their chemical analyses, contain sulfur compounds, phenols, and flavonoids. The sulfur compounds are characterized by having a neurotoxic mode of action since they act on the octopaminergic system of insects, inhibiting neurotransmitters such as octopamine, which leads to the total decomposition of the nervous system, altering the locomotor activity that leads to paralysis and the insect's death (Chaubey, 2017; Plata-Rueda et al., 2017).

Regarding phenolic compounds, the mode of action has been shown to be concentration-dependent (Pereira et al., 2006). At low concentration levels, they generate changes in the membrane due to $\mathrm{K}^{+}$leaks (Walsh et al., 2003). The activity of these compounds is also related to their ability to denature proteins, which generally classifies them as active surface agents (Pereira et al., 2006).

Based on the different metabolites provided by each extract and considering that all of them presented a response to the thrips larvae, the extracts were combined at different concentrations. The relative proportion of each extract with respect to the equivalent was measured in $\mu \mathrm{g} \cdot \mathrm{mL}^{-1}$ in each combination. The percentages of mortality (\%) for the combinations of $A$. muricata $\mathrm{L}$. and $A$. fistulosum $\mathrm{L}$. extracts versus the T. tabaci L. larvae are presented in Table 2.
It can be noted that all the combinations showed insecticidal activity and achieved mortalities between $50 \%$ and $75 \%$, with combination 3 reaching the highest mortality percentage ( $72.62 \%)$, a result that does not statistically differ from the negative control, and which poses an alternative for controlling thrips.

Although the combinations of the extracts resulted in mortalities lower than that reached by the $A$. muricata $\mathrm{L}$. extract individually, which indicates that there is no synergy between the extracts of $A$. fistulosum L. and A. muricata L., the results obtained by combination 3 show a very significant percentage of mortality. This mixture is enriched in sulfides, alkaloids, acetogenins, and phenolic compounds, which can provide different mechanisms of biocidal activity and, therefore, have a great potential for controlling thrips.

Table 2. Mortality (\%) of Thrips tabaci L. larvae caused by the mixtures of Annonaceae and Allium fistulosum L. extracts, the agricultural insecticide Acaramik and $0.04 \%$ DMSO solution. The results were determined at $23^{\circ} \mathrm{C} \pm 1{ }^{\circ} \mathrm{C}$ and $\mathrm{RH}$ at $25 \% \pm 10 \%$.

\begin{tabular}{lcc}
\hline \multicolumn{1}{c}{ Treatment } & \% Mortality & $\begin{array}{c}\text { \% Mortality with } \\
\text { abbott correction }\end{array}$ \\
\hline Blank & $16.67 \pm 1.18 \mathrm{a}$ & 0.0 \\
Combination 1 & $50.76 \pm 1.88 \mathrm{~b}$ & 40.1 \\
Combination 2 & $58.4 \pm 1.75 \mathrm{~b}$ & 50.1 \\
Combination 3 & $72.62 \pm 0.91 \mathrm{bc}$ & 67.1 \\
Insecticide & $100.0 \pm 1.97 \mathrm{c}$ & 100.0 \\
CV & & 27.55 \\
\hline
\end{tabular}

The means ( \pm SE) followed by the same lowercase letters in a column do not differ by $5 \%$ probability with the Tukey test. 
The observations recorded during the tests showed that thrips larvae that were dead $24 \mathrm{~h}$ after the application of the biocidal mixture presented a darker shade (Figure $3 \mathrm{C}$ ) with respect to their original color (Figure $3 \mathrm{~A}$ ). This behavior was also observed in the individual assessment of Annonaceae extract.

The above results respond to the mode of action of acetogenins and alkaloids, metabolites found in abundance in the seeds of fruit species of the Annonaceae family, and function as insecticides and food deterrents (Colom et al.,
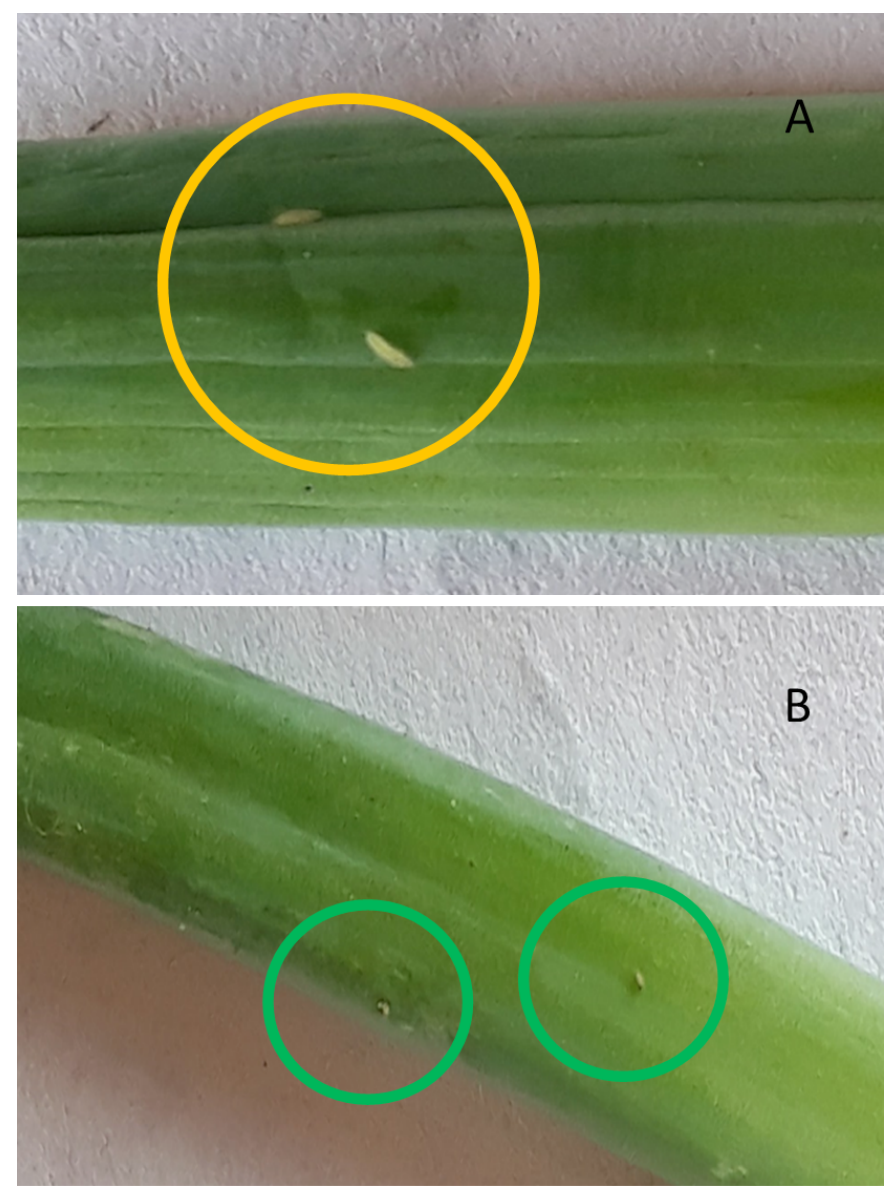

C

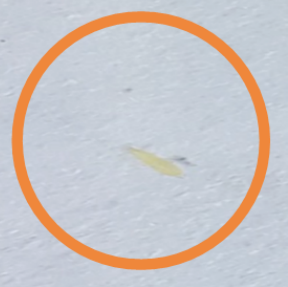

Figure 3. Photographic record of the biocidal activity trials for Annonaceae and Amaryllidacae extracts. A. Live Thrips larvae on onion leaves. B. Dead and immobile Thrips larvae after the application of onion extracts. C. Dried Thrips larvae after application of the Annonaceae extract.
2007; Rattan, 2010), what confirms that the presence of these metabolites contributes to the biocidal activity.

On the contrary, the thrips larvae that were found dead in the biocidal evaluation of the $A$. fistulosum L. extracts retained their original color despite being immobilized. Muscle contraction was also noted in some cases (Figure $3 \mathrm{~B}$ ), which are effects that can attribute to the sulfur compounds, as well as to synergy with the phenolic compounds that are contributing to the biocidal activity.

Studies on A. fistulosum L. have indicated that their polar extracts have a high potential for toxicity (Denloye, 2010) and antifungal (Sang et al., 2002; Pyun \& Shin, 2006) and antibacterial activity (Benkeblia, 2004; Chang et al., 2016). There are reports of the ovicidal action of the essential oil (Denloye, 2010) as well as nematicidal and antimicrobial activity, especially in those with trisulfide and thiosulphate groups (Tada \& Hiroe, 1988). The activity is mainly attributed to the instability of these compounds, which leads to rearrangements and, consequently, to a great variety of derivatives with important biological activities (Benkeblia, 2004; Lanzotti, 2006).

\section{Conclusion}

The Annonaceae and A. fistulosum L. extracts presented important lethality against the plague insect $T$. tabaci L. and can be very promising, both individually and in a mixture, for this pest's comprehensive management. However, the study should be continued with field tests to define its effectiveness as well as to establish the residual of the active components.

\section{Acknowledgments}

The authors would like to thank the Science, Technology and Innovation Administration Department, COLCIENCIAS for funding the project "Harmonization of agricultural use and conservation of water resources for human supply. Case study: onion crops in the middle-upper basin of the Otún river, Department of Risaralda" within the framework of the 713 call of 2016.

\section{Literatura Cited}

Arevalo, A.; Bacca, T.; Soto G, A. Diagnóstico del uso y manejo de plaguicidas en fincas productoras de cebolla junca Allium fistulosum en el municipio de Pasto. Luna Azul, n.38, p.132145, 2014. http://www.scielo.org.co/scielo.php?pid=S190924742014000100008\&script=sci_arttext\&tlng=en. 01 Apr. 2019.

Azazy, A. M.; Abdelall, M. F. M.; El-Sappagh, I. A.; Khalil, A. E. H. Biological control of the onion thrips, Thrips tabaci Lindeman (Thysanoptera: Thripidae), in open fields using Egyptian entomopathogenic nematode isolates. Egyptian Journal of Biological Pest Control, v.28, n.1, article 27, 2018. https://doi. org/10.1186/s41938-017-0025-9. 
Benkeblia, N. Antimicrobial activity of essential oil extracts of various onions (Allium cepa) and garlic (Allium sativum). LWT - Food Science and Technology, v.37, n.2, p. 263-268, 2004. https://doi. org/10.1016/j.lwt.2003.09.001.

Calderón-Oliver, M.; Escalona-Buendía, H. B.; Medina-Campos, O. N.; Pedraza-Chaverri, J.; Pedroza-Islas, R.; Ponce-Alquicira, E. Optimization of the antioxidant and antimicrobial response of the combined effect of nisin and avocado by products. LWT Food Science and Technology, v 65, p. 46-52, 2016. https://doi. org/10.1016/j.Iwt.2015.07.048.

Castro, L.; Alzate, M.; Guerrero, G. Estudio preliminar de la bioactividad de extractos de semillas de Annona cherimolia de la familia Annonaceae. Scientia et Technica, v.1, n. 44, p. 326-330, 2010. https://dialnet.unirioja.es/servlet/articulo?codigo $=4584726.09$ Apr. 2019.

Celestino, F. N.; Pratissoli, D.; Machado, L. C.; Santos Junior, H. J. G.; Queiroz, V. T.; Mardgan, L. Control of coffee berry borer, Hypothenemus hampei (Ferrari) (Coleoptera: Curculionidae: Scolytinae) with botanical insecticides and mineral oils. Acta Scientiarum. Agronomy, v. 38, n.1, e27430, 2016. https://doi. org/10.4025/actasciagron.v38i1.27430.

Celis, Á.; Mendoza, C.; Pachón, M.; Cardona, J.; Delgado, W.; Cuca, L. E. Extractos vegetales utilizados como biocontroladores con énfasis en la familia Piperaceae. Una revisión. Agronomía Colombiana, v. 26, n. 1, p. 97-106, 2008. http://www.scielo.org. co/pdf/agc/v26n1/v26n1a12.pdf. 29 Mar. 2019.

Chang, T.; Jang, H.; Lin, W.; Duan, P. Antioxidant and antimicrobial activities of commercial rice wine extracts of Taiwanese Allium fistulosum. Food Chemistry, v. 190, p. 724-729, 2016. https://doi. org/10.1016/j.foodchem.2015.06.019.

Chaubey, M. K. Study of insecticidal properties of garlic, Allium sativum (Alliaceae) and bel, Aegle marmelos (Rutaceae) essential oils against Sitophilus zeamais L. (Coleoptera: curculionidae). Journal of Entomology, v. 14, n. 5, p. 191-198, 2017. https://doi. org/10.3923/je.2017.191.198.

Colom, O. A.; Neske, A.; Popich, S.; Bardón, A. Toxic effects of Annonaceous acetogenins from Annona cherimolia (Magnoliales: Annonaceae) on Spodoptera frugiperda (Lepidoptera: Noctuidae). Journal of Pest Science, v. 80, n. 1, p. 63-67, 2007. https://doi.org/http://dx.doi.org/10.1007/s10340-006- 0149-2.

Denloye, A. A. Bioactivity of powder and extracts from garlic, Allium sativum L. (Alliaceae) and spring onion, Allium fistulosum L. ( Alliaceae) against Callosobruchus maculatus F. (Coleoptera: Bruchidae) on cowpea, Vigna unguiculata (L.) Walp (Leguminosae) seeds. Psyche, v. 2010, Article ID 958348, 2010. https://doi.org/10.1155/2010/958348.

Dos Santos, L.; Trindade, R.P.; Dos Santos, D. S.; Dos Santos, M.; Broglio, S. M.F.; Lemos, E. E. P. Effect of anonaceous extracts on Aphis gossypii (Glover, 1887) (Hemiptera: Aphididae) and selectivity to Eriopis connexa (Germar, 1824) (Coleoptera: Coccinellidae). Acta Scientiarum. Agronomy, v. 40, n. 1, e36267, 2018. https://doi.org/10.4025/actasciagron.v40i1.36267.

Egydio-Brandão, A. P. M.; Novaes, P.; Santos, D. Y. A. C. Alkaloids from Annona Review from 2005 to 2016. JSM Biochemistry \& Molecular Biology, v. 4, n. 3, e1031, 2017. https://www. jscimedcentral.com/Biochemistry/biochemistry-4-1031.pdf. 05 Apr. 2019.
Garrido, G.; Ortiz, M.; Pozo, P. Fenoles y flavonoides totales y actividad antioxidante de extractos de hojas de Lampaya medicinalis F. Phil. Journal of Pharmacy and Pharmacognosy Research, v. 1, n. 1, p. 30-38, 2013. http://jppres.com/jppres/ pdf/vol1/1_1_30.pdf. 01 Apr. 2019.

Giraldo, A.; Guerrero, G. Rollinia mucosa (Jacq.) Baillon (Annonaceae) active metabolites as alternative biocontrol agents against the lace bug Corythucha gossypii (Fabricius): an insect pest. Universitas Scientiarum, v. 23, n. 1, p. 21-34, 2018. https://doi.org/10.11144/Javeriana.SC23-1.rmjb.

Gîtin, L.; Dinicə, R.; Neagu, C.; Dumitrascu, L. Sulfur compounds identification and quantification from Allium spp. fresh leaves. Journal of Food and Drug Analysis, v. 22, n. 4, p. 425-430, 2014. https://doi.org/10.1016/j.jfda.2014.04.002.

Grzybowski, A.; Tiboni, M.; da Silva, M. A. N.; Chitolina, R. F.; Passos, M.; Fontana, J. D. The combined action of phytolarvicides for the control of dengue fever vector, Aedes aegypti. Brazilian Journal of Pharmacognosy, v. 22, n. 3, p. 549-557, 2012 https://doi.org/10.1590/S0102-695X2012005000026.

Guzmán, S.; Palacios, M. Instrumentos de política para la gestión de Servicios ecosistémicos en agro-ecosistemas cebolleros de la cuenca del río Otún, Colombia. Recursos Naturales y Ambiente, v. 58, p. 51-58, 2018. http://repositorio. bibliotecaorton.catie.ac.cr/bitstream/handle/11554/6418/ Instrumentos_depolitica_pdf.pdf?sequence=1\&isAllowed=y. 05 Apr. 2019.

Kameoka, H.; lida, H.; Hashimoto, S.; Miyazawa, M. Sulphides and furanones from steam volatile oils of Allium fistulosum and Allium chinense. Phytochemistry, v. 23, n. 1, p. 155-158, 1984 https://doi.org/10.1016/0031-9422(84)83097-6.

Khaliq, A.; Khan, A. A.; Afzal, M.; Tahir, H. M.; Raza, A. M.; Khan, A. M. Field Evaluation of selected botanicals and commercial synthetic insecticides against Thrips tabaci Lindeman (Thysanoptera: Thripidae) populations and predators in onion field plots. Crop Protection, v. 62, p.10-15, 2014. https://doi org/10.1016/j.cropro.2014.03.019.

Lanzotti, V. The analysis of onion and garlic. Journal of Chromatography A, v. 1112, n. 2, p. 3-22, 2006. https://doi org/10.1016/j.chroma.2005.12.016.

Lebedev, G.; Abo-Moch, F.; Gafni, G.; Ben-Yakir, D.; Ghanim, M. High-level of resistance to spinosad, emamectin benzoate and carbosulfan in populations of Thrips tabaci collected in Israel. Pest Management Science, v. 69, n. 2, p. 274-277, 2013. https://doi.org/10.1002/ps.3385.

Leite, G. L. D.; Silva, F. W. S.; Guanabens, R. E. M.; Fernandes, L. A.; Figueiredo, L. S.; Silva, L. F. NPK and flavonoids affecting insect populations in Dimorphandra mollis seedlings. Acta Scientiarum. Agronomy, v. 34, n. 1, p. 17-22, 2012. https:// doi.org/10.4025/actasciagron.v34i1.11233.

Llana-Ruiz-Cabello, M.; Maisanaba, S.; Gutiérrez-praena, D.; Prieto, A. I.; Pichardo, S.; Jos, Á.; Moreno, F. J.; Cameán, A. M. Cytotoxic and mutagenic in vitro assessment of two organosulfur compounds derived from onion to be used in the food industry. Food Chemistry, v. 166, p. 423-431, 2015 https://doi.org/10.1016/j.foodchem.2014.06.058. 
Martin, N. A.; Workman, P. J.; Butler, R. C. Insecticide resistance in onion thrips (Thrips tabaci) (Thysanoptera: Thripidae). New Zealand Journal of Crop and Horticultural Science, v. 31, n. 2, p. 99-106, 2003. https://doi.org/10.1080/01140671.2003.951424 2.

McLaughlin, J. L. Paw paw and cancer: Annonaceous acetogenins from discovery to commercial products. Journal of Natural Products, v. 71, n. 7, p. 1311-1321, 2008. https://doi.org/10.1021/ np800191t.

Moghadamtousi, S.; Fadaeinasab, M.; Nikzad, S.; Mohan, G.; Ali, H. M.; Kadir, H. A. Annona muricata (Annonaceae): a review of its traditional uses, isolated acetogenins and biological activities. International Journal of Molecular Sciences, v. 16, n. 7, p. 1562515658, 2015. https://doi.org/10.3390/ijms160715625.

Murillo, J. Las Annonaceae de Colombia. Biota Colombiana, v. 2, n. 1, p. 49-58, 2001. http://www.redalyc.org/pdf/491/49120104.pdf. 29 Mar. 2019.

Nazemi,A.; Khajehali,J.;VanLeeuwen, T.Incidenceand characterization of resistance to pyrethroid and organophosphorus insecticides in Thrips tabaci (Thysanoptera: Thripidae) in onion fields in Isfahan, Iran. Pesticide Biochemistry and Physiology, v. 129, p. 28-35, 2016. https://doi.org/10.1016/j.pestbp.2015.10.013.

Nwankwo, E. N.; Okonkwo, N. J.; Ogbonna, C. U.; Akpom, C. J. O.; Chukwudi, M. Moringa oleifera and Annona muricata seed oil extracts as biopesticides against the second and fourth larval instar of Aedes aegypti L. (Diptera: Culicidae). Journal Biopest, v. 8, n. 1, p. 56-61, 2015. http://www.jbiopest.com/users/LW8/ efiles/vol_8_1_56-61.pdf. 01 Apr. 2019.

Ortiz, R.; Gonzáles, C.; Castaño, J. Etiología de la punta blanca de la cebolla (Allium fistulosum L.) en la granja tesorito, Manizales Caldas. Revista de La Academia Colombiana de Ciencias Exactas, Fisicas y Naturales, v. 36, n. 140, p. 365-372. 2012. https://www. researchgate.net/publication/262504462. 10 Apr. 2019.

Patil, V.V.; Kabre, G.B.; Dixit, S.S.; Desale, S.B. Evaluation of entomophathogenic fungi against onion thrips, Thrips tabaci (Lindeman). International Journal of Plant Protection, v. 9, n. 1, p. 168-171, 2016. https://doi.org/10.15740/HAS/IJPP/9.1/168171.

Pereira, J. A.; Pereira, A. P.; Ferreira, I. C.; Valentão, P.; Andrade, P. B.; Seabra, R.; Estevinho, L.; Bento, A. Table olives from Portugal: phenolic compounds, antioxidant potential, and antimicrobial activity. Journal of Agricultural and Food Chemistry, v. 54, n. 22, p. 8425-8431, 2006. https://doi.org/10.1021/jf061769j.

Pino, O.; Sánchez, Y.; Rojas, M. M. Plante metabolitos secundarios como alternativas en el manejo de plagas. II: una visión general de su potencial en Cuba. Revista de Protección Vegetal, v. 28, n. 2, p. 95-108, 2013. http://scielo.sld.cu/scielo.php?script=sci_art text\&pid=S1010-27522013000200002. 29 Mar. 2019.

Plata-Rueda, A.; Martínez, L. C.; Santos, M. H.D.; Fernandes, F. L.; Wilcken, C. F.; Soares, M. A.; Serrao. J.E.; Zanuncio, J. C. Insecticidal activity of garlic essential oil and their constituents against the mealworm beetle, Tenebrio molitor Linnaeus (Coleoptera: Tenebrionidae). Scientific Reports, v. 7, article 46406, 2017. https://doi.org/10.1038/srep46406.
Pyun, M.; Shin, S. Ã. Antifungal effects of the volatile oils from Allium plants against Trichophyton species and synergism of the oils with ketoconazole. Phytomedicine, v. 13, n. 6, p. 394-400, 2006. https://doi.org/10.1016/j.phymed.2005.03.011.

RAPAL Uruguay. Contaminación y eutrofización del agua Impactos del modelo de agricultura industrial. Montevideo: RAPAL Uruguay, 2010. 36p. http://www.rapaluruguay.org/agrotoxicos/Uruguay/ Eutrofizacion.pdf. 10 Mar. 2019. Rattan, R. S. Mechanism of action of insecticidal secondary metabolites of plant origin. Crop Protection, v. 29, n. 9, p. 913-920, 2010. https://doi.org10.1016/j. cropro.2010.05.008.

Roldán, E.; Sánchez-Moreno, C.; Ancos, B. D. E. Subproductos de cebolla como ingredientes alimentarios con propiedades antioxidantes e inhibidoras del pardeamiento enzimático. In: Congreso Iberoamericano de Tecnologia Postcosecha y Agroexportaciones, 5., 2007, Cartagena. Anales... Curico: Universidad Católica del Maule; Cartagena: Universidad Politécnica de Cartagena, 2007. v. 1, p. 559-570.

Sang, S.; Lao, A.; Wang, Y.; Chin, C.K.; Rosen, R. T.; Ho, C.T. Antifungal constituents from the seeds of Allium fistulosum L. Journal of Agricultural and Food Chemistry, v. 50, n. 22, p. 6318-6321, 2002. https://doi.org/10.1021/jf025651o.

Satyanarayana, P.; Singh, P. Relative field efficacy of botanicals, biopesticides and synthetic insecticides against thrips (Thrips tabaci Lind) on onion. Journal of Experimental Zoology, v. 19, n. 1, p. 191-194, 2016. http://www.connectjournals.com/achivestoc2. php?fulltext=2430801H_191-194.pdf\&\&bookmark=CJ033215\&\&issue_id=01\&\&yaer=2016. 07 Apr. 2019.

Soto, V. C.; Maldonado, I. B.; Jofré, V. P.; Galmarini, C. R.; Silva, M. F. Direct analysis of nectar and floral volatile organic compounds in hybrid onions by HS-SPME/GC-MS: Relationship with pollination and seed production. Microchemical Journal, v. 122, p. 110-118, 2015. https://doi.org/10.1016/j.microc.2015.04.017.

Souza, C. M.; Baldin, E. L. L.; Ribeiro, L. P.; Silva, I. F.; Morando, R.; Bicalho, K. U.; Vendramim, J.D.; Fernandes, J. B. Lethal and growth inhibitory activities of Neotropical Annonaceae-derived extracts, commercial formulation, and an isolated acetogenin against Helicoverpa armigera. Journal of Pest Science, v. 90, n. 2, p. 701-709, 2017. https://doi.org/10.1007/s10340-016-0817-9.

Tada, M.; Hiroe, Y.; Kiyohara, S.; Suzuki, S. Nematicidal and antimicrobial constituents from Allium grayi Regel and Allium fistolosum L. var. caespitosum. Agricultura and Biological Chemestry, v. 52, n. 9, p. 2383-2385, 1988. https://doi.org/10.10 80/00021369.1988.10869050.

Walsh, S. E.; Maillard, J. Y.; Russel, A. D.; Catrenich, C. E.; Charbonneau, A. L.; Bartolo, R. G. activity and mechanism of action of selected biocidal agents on gram -positive and -negative bacteria. Journal of Applied Microbiology, v. 94, n.2, p. 240-247, 2003. https://doi. org/10.1046/j.1365-2672.2003.01825.x.

Zamar, M. I.; Arce de Hamity, M. G.; Andrade, A.; Amendola de Olsen, A.; Hamity, V. Efecto de productos no convencionales para el control de Thrips tabaci (Thysanoptera: Thripidae) en el cultivo de Ajo (Allium sativum) en la Quebrada de Humahuaca (Jujuy-Argentina). Idesia, v. 25, n. 3, p. 41-46, 2007. https://doi. org/10.4067/S0718-34292007000300005. 